\title{
Cyanide in Cassava Varieties and People's Perception on Cyanide Poisoning in Selected Regions of Tanzania
}

\author{
Cornelius B. Mushumbusi \\ ${ }^{1}$ Department of Education, Curriculum and Instruction, Mwenge Catholic University, P.O. \\ Box 1226, Moshi, Tanzania \\ Email: cbmushumbusi@gmail.com
}

\begin{abstract}
Robert A. Max (Corresponding Author)
Department of Veterinary Physiology, Biochemistry and Pharmacology, P.O. Box 3017, College of Veterinary and Biomedical Sciences, Sokoine University of Agriculture, Morogoro,

Tanzania. Email: robertmax@sua.ac.tz
\end{abstract}

\begin{abstract}
Gaymary G. Bakari
Department of Veterinary Physiology, Biochemistry and Pharmacology, P.O. Box 3017, College of Veterinary and Biomedical Sciences, Sokoine University of Agriculture, Morogoro, Tanzania. Email: gaymary.bakari@sua.ac.tz

James R. Mushi

Department of Veterinary Physiology, Biochemistry and Pharmacology, P.O. Box 3017, College of Veterinary and Biomedical Sciences, Sokoine University of Agriculture, Morogoro, Tanzania. Email: jamessalakana_1979@sua.ac.tz
\end{abstract}

\section{Sakurani T. Balthazary}

Department of Veterinary Physiology, Biochemistry and Pharmacology, P.O. Box 3017, College of Veterinary and Biomedical Sciences, Sokoine University of Agriculture, Morogoro,

Tanzania. Email: sakurani1955@yahoo.com

Received: Sep. 24, 2019

doi:10.5296/jas.v8i1.15511
Accepted: Oct. 27, 2019 Published: Nov. 7, 2019

URL: https://doi.org/10.5296/jas.v8i1.15511 


\section{Abstract}

Cassava, an important food crop in the tropical regions of the world, is known to carry varying levels of cyanogenic glucosides that are potential poison to humans. In Tanzania, cases of cyanide poisoning have been reported in many cassava producing areas. This study was launched to quantify cyanide in fresh tubers of so called "sweet" cassava varieties and to gauge peoples' perception on cyanide poisoning in Kagera and Morogoro regions. The study employed a questionnaire survey and a cross-sectional research design to identify different cassava varieties and their cyanide content using alkaline titration method. Findings showed that cyanide content in all of the analyzed tubers were above the internationally accepted levels in human consumables. Some sweet varieties were found to be wrongly classified as sweet because their cyanide content was above acceptable limits. For the same variety tubers sampled from a lowland area had significantly higher $(\mathrm{P}<0.01)$ cyanide content than those from a highland point. It was also found that the upper (slippery) parenchymal tissue had more cyanide content $(\mathrm{P}<0.05)$ than the inner tissue. Nearly $80 \%$ of the studied population was unaware of cyanide poisoning, its health effects and how to reduce cyanide content prior to consumption. It is concluded that consumption of raw cassava tubers can lead to undesirable health effects despite of some of them being categorized as sweet. The public should be sensitized on the issues of cyanide in cassava and should avoid consuming raw cassava tubers as preventive measures against cyanide poisoning.

Keywords: cassava varieties, cyanide levels, cyanide poisoning

\section{Introduction}

Cassava (Manihot esculenta Crantz) is a perennial crop native to tropical America (Allem, 1994) and an important and cheap source of carbohydrate in tropical and sub-tropical regions, particularly in Sub-Sahara Africa. The cassava plant grows faster compares to other crops (Nhassico et al., 2008; Tivana et al., 2014; Ubwa et al., 2015) and has remarkable ability to withstand harsh climatic conditions. These two qualities have made the diverse edible varieties of cassava to be an outstanding crop that saves at least 500 million of human lives from hunger worldwide. About $56 \%$ of the world's cassava production has its source in Africa and Tanzania is among the leading producer countries in the world (FAO, 2013). Apart from being a popular staple crop and a superb source of carbohydrates and minerals (Mburu, 2013; Mercola, 2016), cassava carries a potential danger of cyanide poisoning (Babalola, 2014), as it contains cyanogenic glycosides, mainly linamarin: $2-\beta$-D-glucopyranosyloxy-2-methylpropane nitrile, and lotaustralin: 2- $\beta$-D-glucopyranosyloxy-2-methylbutyronitrile (Idible, 2006). On hydrolysis in the human gut, the cyanogens produce hydrocyanic acid which is toxic (Tivana et al., 2014). Cyanide is responsible for several health complications such as Konzo disease, thyroid goiter and tropical ataxic neuropathy, TAN (Kobawila et al., 2005), incidences of cretinism, stunted growth in children and deaths (Nhassico et al., 2008), epilepsy (Ngugi et al., 2013) as well as behavioral and emotional abnormalities in children (Kariuki et al., 2017). 
Risk factors associated with cyanide poisoning include: the existence of a large number of cassava varieties (bitter and sweet) which differ in cyanide levels, stage of maturity, soil type (Cardoso et al., 2004; Famurewa and Emuekele, 2014; Ubwa et al., 2015) as well as the habit of consuming raw cassava tubers by some communities. Although cyanide levels in cassava tubers can be reduced using simple traditional methods such as boiling, roasting, drying, grating, soaking and fermentation (Ernesto et al., 2002; Nzwalo and Cliff, 2011), consumption of raw cassava tubers is being practiced probably due to lack of awareness of potential dangers of cyanide poisoning. Furthermore, local classification of cassava varieties as "sweet" (i.e., non-poisonous) has added to the complacency in employing the simple treatments to reduce cyanide levels in tubers before consumption. This is because even those cassava cultivars considered sweet have been a source of disaster to humans in East Africa (Mburu et al., 2011).

The current study was therefore carried out to quantify levels of cyanide in raw cassava tubers of various varieties cultivated in Kagera and Morogoro regions and gauge people's knowledge and perception on cyanide poisoning. Findings from the study were expected to shed more light on cyanide levels in different cassava varieties, a prerequisite for formulation of proper advice against cyanide poisoning and its associated health effects.

\section{Materials and Methods}

\subsection{Research Site}

The study was done in Bukoba Rural and Missenyi districts of Kagera Region and in Morogoro Municipality and Mvomero district of Morogoro Region, Tanzania. In the two regions, cassava is widely grown and consumed raw in addition to being a staple food. Moreover, cases of cyaniding poisoning as well as indicators of cyanide poisoning in Kagera and Morogoro regions were another reason of undertaking the study in the two regions. Kagera region is located in the northwestern corner of Tanzania on the western shore of Lake Victoria, lying between $1^{\circ} 00^{\prime} 2.45^{\prime}$ 'S, $30^{\circ} 25^{\prime} 32.41^{\prime \prime} \mathrm{E}$ with the elevation of 1,200 $\mathrm{m}$ above sea level (MASL). Morogoro region is located in eastern part of Tanzania; lying between $6^{\circ} 41^{\prime} 15.67^{\prime \prime}$ S, 37 39'40.39'E at an average altitude of 525 MASL. Determination of cyanide levels in the sample cassava tubers was done at the Food Science Research Laboratory, Sokoine University of Agriculture (SUA) Morogoro, Tanzania.

\subsection{Study Design and Questionnaire Survey}

This study used cross-sectional design and purposive inclusion of participants (cassava growers and consumers) to collect responses from 386 participants through administration of a structured questionnaire. The number of participants was arrived at by employing Smith's formula (Smith, 2013) which is only applied to unknown or too large a population. This survey assisted in identifying (by local names) the "sweet" cassava varieties grown in Kagera and Morogoro regions as well as obtaining people's perception on cyanide in cassava tubers and its poisoning effects with respect to cassava consumption. 


\subsection{Sampling of Cassava Tubers}

Following identification of common cassava sweet varieties, simple random sampling was employed to obtain twelve sample varieties that were used for the cyanide quantification study. From these 12 sample varieties, 66 fresh mature tubers were collected in such a way that each variety was represented by not less than five tubers each obtained from a different farm in the study area. Furthermore, tubers of three sample varieties were purposively collected from highland (Magadu Ward) and lowland (Mzinga Ward) areas of Morogoro Municipality for assessment of any effects of altitude on cyanide content. All the tubers from selected locations were transported to the laboratory within two days of their harvesting to meet their limited shelf life.

\subsection{Quantification Cyanide Levels}

At the laboratory, the tubers were preserved in a refrigerator $\left(\right.$ at $\left.4{ }^{\circ} \mathrm{C}\right)$ until analysis. The cyanide levels were determined using alkaline titration method (AOAC, 1995). Briefly, tubers were washed and then peeled to obtain the parenchyma. The parenchyma was longitudinally cut into several portions, which were ground using an electric blender to obtain ground parenchyma tissue from which two portions each weighing $20 \mathrm{~g}$ were used. Each of the portions was placed into $800 \mathrm{~mL}$ Kjeldahl flask and then mixed with $200 \mathrm{~mL}$ distilled water. The mixture was left to stand for at least two hours for complete enzymatic process; this was followed by steam-distillation of the mixture to collect $150 \mathrm{~mL}$ distillate in $\mathrm{NaOH}$ solution $\left(0.5 \mathrm{~g}\right.$ in $\left.20 \mathrm{~mL} \mathrm{H}_{2} \mathrm{O}\right)$ contained in a flat-bottomed flask. To $100 \mathrm{~mL}$ of the distillate, $8 \mathrm{~mL} 6 \mathrm{~N}$ $\mathrm{NH}_{4} \mathrm{OH}$ and $2 \mathrm{~mL} 5 \% \mathrm{KI}$ solution were added and then titrated with $0.02 \mathrm{~N} \mathrm{AgNO}_{3}$ using micro-burette. The average titre volume for the results obtained from the two $20 \mathrm{~g}$ - portions of the sample tuber was recorded. Eventually, cyanide content for each average titre volume was calculated by using the formula for alkaline titration method: $1 \mathrm{~mL} 0.02 \mathrm{~N} \mathrm{AgNO}_{3}=1.08$ $m g H C N$ (AOAC, 1995). The calculated values were in turn used to work out $\mathrm{mg}(\mathrm{HCN})$ per $\mathrm{kg}$ of fresh cassava.

\subsection{Distribution of Cyanide Levels in the Parenchyma}

Distribution of cyanide in cassava tuber parenchyma was determined using three samples each representing a different variety. From each sample, $20 \mathrm{~g}$ were scratched off from the upper (slippery) tissue and $20 \mathrm{~g}$ from the adjacent inner tissue of the tuber parenchyma. Each of these portions was placed into $800 \mathrm{~mL}$ Kjeldahl flask and then mixed with $200 \mathrm{~mL}$ distilled water and underwent the remaining steps of the procedure as already described above to obtain the titre volume with eventual determination of cyanide level for each titre volume.

\subsection{Statistical Analysis}

The questionnaire data were handled by Microsoft Excel (2010) analyzed using Statistical Package for Social Sciences (SPSS, 2015) to calculated percentage responses, means and standard deviations. ANOVA was also carried out to test different hypotheses. 


\section{Results}

\subsection{Cassava Varieties Grown in Kagera and Morogoro Regions}

Fifty two common sweet cassava varieties (their local names in capital letters) were identified; 22 from Morogoro and 30 from Kagera regions, as presented in Table 1. The most mentioned varieties were BUKARAZA (Kagera Region) and BETAUJE (Morogoro Region), whereas the least common varieties in the two regions were SILA and MPERA respectively.

Table 1. Cassava varieties grown in Kagera and Morogoro regions including frequency and percent of variety's turns of mention

\begin{tabular}{lcclcc}
\hline \multicolumn{7}{c}{ Kagera region } & & \multicolumn{3}{c}{ Morogoro region } \\
\hline Cassava variety & $\begin{array}{c}\text { Frequency } \\
\text { of mention }\end{array}$ & $\begin{array}{c}\text { Percent } \\
(\%)\end{array}$ & Cassava variety & $\begin{array}{c}\text { Frequency } \\
\text { of mention }\end{array}$ & $\begin{array}{c}\text { Percent } \\
(\%)\end{array}$ \\
\hline BUKARAZA & 125 & 67.9 & BETAUJE & 107 & 52.9 \\
RUSHULA & 113 & 61.4 & NYACHILO & 95 & 47.0 \\
KATAAKYA & 102 & 55.4 & KIGOMA-TANGA & 85 & 40.1 \\
PIKIPIKI & 87 & 47.3 & KIKANIKI & 75 & 37.1 \\
KAEMPU & 86 & 46.7 & MOSHI-WA-TAA & 72 & 35.6 \\
SUNGUSUNGU & 85 & 46.2 & SIGARA-BARIDI & 68 & 33.7 \\
SHELEKERA & 82 & 44.6 & KIBAHA & 65 & 32.2 \\
NJUBU & 81 & 44.0 & SIGARA-MWEUPE & 62 & 30.9 \\
RUTUKU & 77 & 41.8 & MWALI-MWEUPE & 61 & 30.2 \\
MAREKANI & 68 & 36.9 & SUPER-TALL & 58 & 28.7 \\
AKIBA & 67 & 36.4 & MZURI-KWAO & 56 & 27.7 \\
KASHANJE & 57 & 30.9 & KIBANGA-MENO & 54 & 26.7 \\
KONYU & 55 & 29.9 & MZUNGU & 50 & 24.8 \\
KARANDILIRA & 55 & 29.9 & MWANGA & 45 & 22.3 \\
SEZARIO & 50 & 27.2 & MNDUNGA & 36 & 17.8 \\
MAMA-ASHA & 46 & 25.0 & MTWIKE & 35 & 17.3 \\
KAGINGO & 45 & 24.5 & MWARUSHA & 33 & 16.3 \\
MBARA & 45 & 24.5 & KISWAHILI & 27 & 13.4 \\
KOMUBEGI & 40 & 21.7 & CHELEMA & 25 & 12.4 \\
MANIMAJEGE & 40 & 21.7 & KIBIBI & 22 & 10.9 \\
NAZARETI & 40 & 21.7 & KISAMBAA & 20 & 9.9 \\
MPOROGOMA & 37 & 20.1 & MPERA & 15 & 7.4 \\
JOJIA & 36 & 19.6 & & & \\
KINOGOFU & 35 & 19.0 & & & \\
KACHALI & 35 & 19.0 & & & \\
KYA-MWANZA & 33 & 17.9 & & & \\
KWATAMPALE & 33 & 17.9 & & & \\
GONYA & 31 & 16.8 & & & \\
MATOKE & 30 & 16.3 & & & \\
SILA & 22 & 11.9 & & & \\
\hline
\end{tabular}

3.2 Cyanide Levels in Cassava Tubers and Varieties Sampled From Different Areas

The 12 sample varieties used for cyanide analysis included PIKIPIKI, SHELEKERA, KATAAKYA, SUNGUSUNGU, AKIBA, KAEMPU and RUSHULA (Kagera Region), KIKANIKI, MZURIKWAO, MWANGA, NYACHILO and KIBAHA (Morogoro Region). Cyanide levels for the 66 cassava tubers collected from Kagera (38 tubers) and Morogoro (28 tubers) regions are presented in Table 2. The highest determined cyanide level $(\mathrm{mg} / \mathrm{kg}$ fresh weight) for each variety was 226.80 (PIKIPIKI), 190.35 (SUNGUSUNGU), 117.05 
(KIKANIKI), 116.64 (MWANGA), 100.85 (MZURIKWAO), 85.05 (AKIBA), 77.76 (KATAAKYA), 75.33 (RUSHULA), 66.83 (SHELEKERA), 64.80 (KIBAHA), 58.73 (KAEMPU) and 47.39 (NYACHILO).

Table 2. Mean tuber cyanide ( $\mathrm{HCN})$ content (mg/kg fresh weight) in selected 12 cassava varieties from Kagera and Morogoro regions

\begin{tabular}{llcrrrrr}
\hline Region & Cassava variety & No. of samples & Mean & STDev & SEM* & Min. & Max. \\
\hline Kagera & PIKIPIKI & 5 & 114.56 & 64.25 & 28.73 & 66.42 & 226.80 \\
& SHELEKERA & 5 & 51.02 & 18.06 & 8.09 & 20.66 & 66.83 \\
& KATAAKYA & 5 & 55.04 & 20.93 & 9.38 & 30.38 & 77.76 \\
& SUNGUSUNGU & 5 & 108.96 & 50.50 & 22.58 & 56.70 & 190.35 \\
& AKIBA & 5 & 49.76 & 26.19 & 11.70 & 19.85 & 85.05 \\
& KAEMPU & 4 & 51.73 & 7.56 & 6.26 & 42.10 & 58.73 \\
& RUSHULA & 9 & 44.84 & 21.13 & 7.99 & 24.30 & 75.33 \\
\hline Morogoro & KIKANIKI & 6 & 64.80 & 30.44 & 12.43 & 40.50 & 117.05 \\
& MZURIKWAO & 6 & 59.06 & 28.50 & 11.63 & 36.45 & 100.85 \\
& MWANGA & 6 & 73.17 & 26.00 & 10.66 & 35.64 & 116.64 \\
& NYACHILO & 5 & 33.13 & 10.11 & 4.52 & 22.68 & 47.39 \\
& KIBAHA & 5 & 46.74 & 12.56 & 5.62 & 31.19 & 64.80 \\
\hline
\end{tabular}

$* \mathrm{SEM}=$ standard error of means

\subsection{Altitude Effect on Cyanide Levels in Three Cassava Varieties}

Comparison of cyanide content for the three varieties (KIKANIKI, MZURIKWAO and MWANGA) sourced from both highland and lowland areas is presented in Figure 1. For each cassava variety, there was significantly higher $(\mathrm{P}<0.01)$ mean cyanide content in tubers collected from lowland areas $(82.62 \mathrm{mg} / \mathrm{kg})$ compared to those from highland areas $(48.74$ $\mathrm{mg} / \mathrm{kg})$.

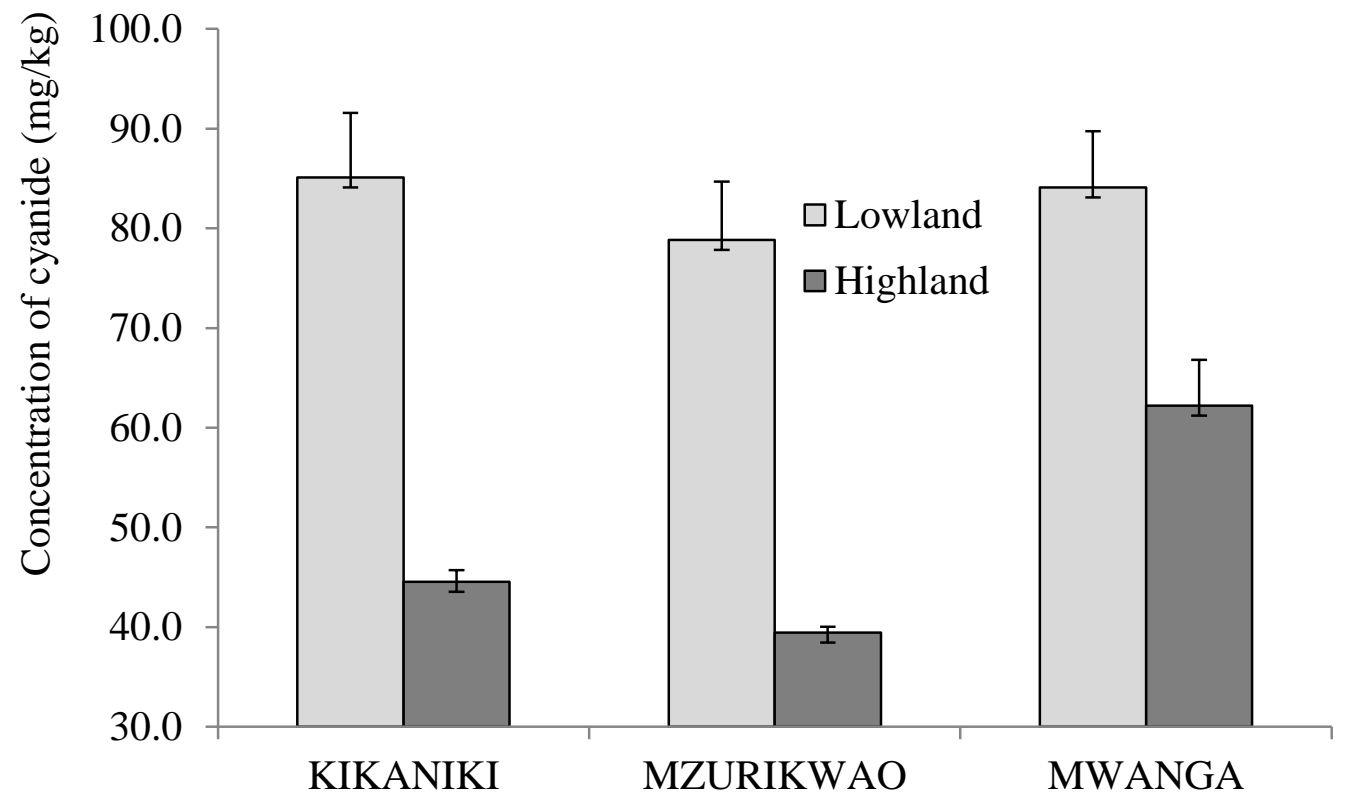

Figure 1. Effect of altitude on concentration of cyanide in selected cassava variety tubers 
3.4 Distribution of Cyanide Between the Upper and Inner Tissue of Cassava Parenchyma

The results for the distribution of cyanide in the upper tissue and inner tissue of the cassava parenchyma for three tested varieties (MZURIKWAO, KIKANIKI and MWANGA) are summarized in Figure 2. The upper slippery layer had significantly higher $(\mathrm{P}<0.05)$ cyanide concentrations than the inner parenchyma for each of the three cassava varieties that were analyzed.

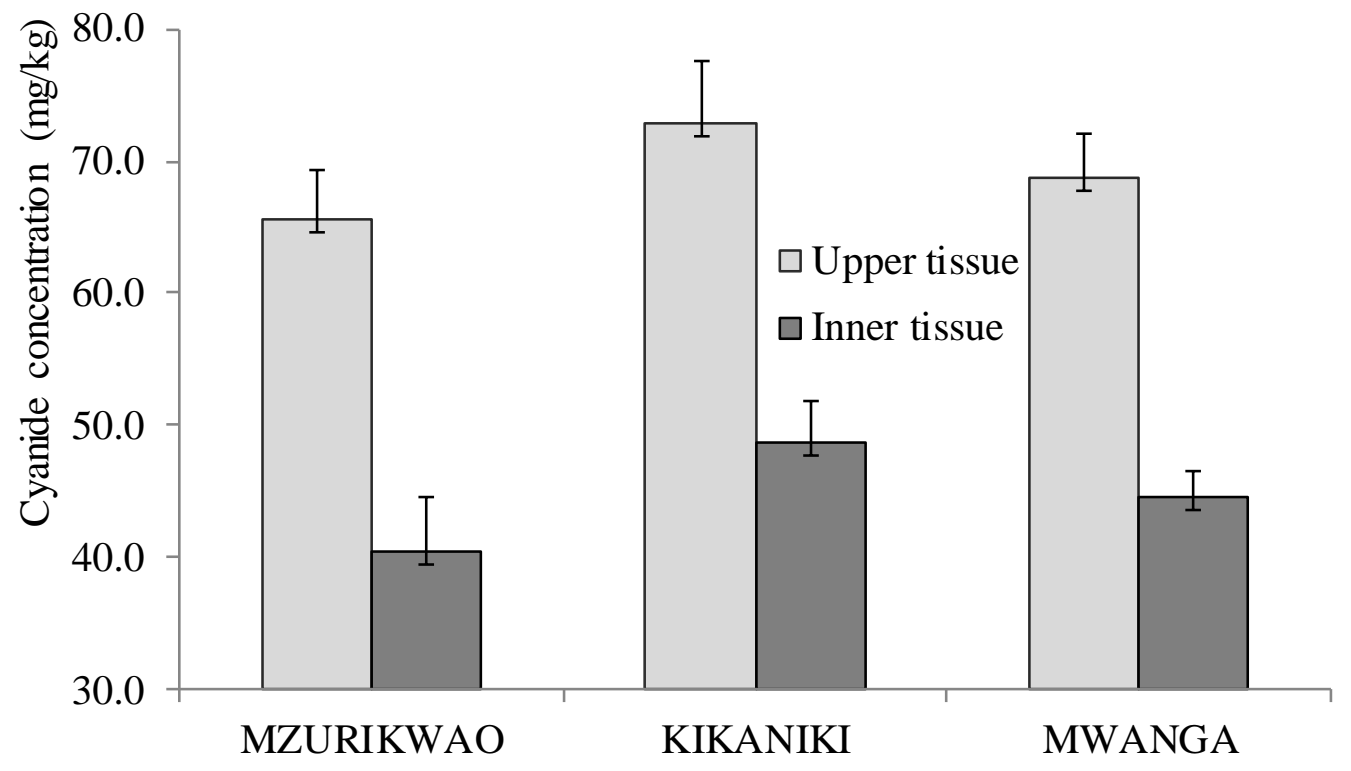

Figure 2. Distribution of cyanide between upper slippery and inner parenchyma of the three selected cassava tubers

\subsection{Peoples'Awareness About Cyanide and Its Poisoning Effects}

Peoples' awareness on different aspects about cyanide and its effects to human health, namely, cyanide quantification method, cyanide depleting methods, cyanide poisoning effects and presence of cyanide in sweet and bitter varieties are summarized Figure 3. About $60 \%$ of the respondents were aware of poisoning by bitter cassava varieties whereas less than $15 \%$ knew of poisoning by the so called sweet varieties. Whereas cyanide poisoning effects and methods for depleting cyanide levels in cassava were equally known by the respondents, none of them were aware of any cyanide quantification methods. 


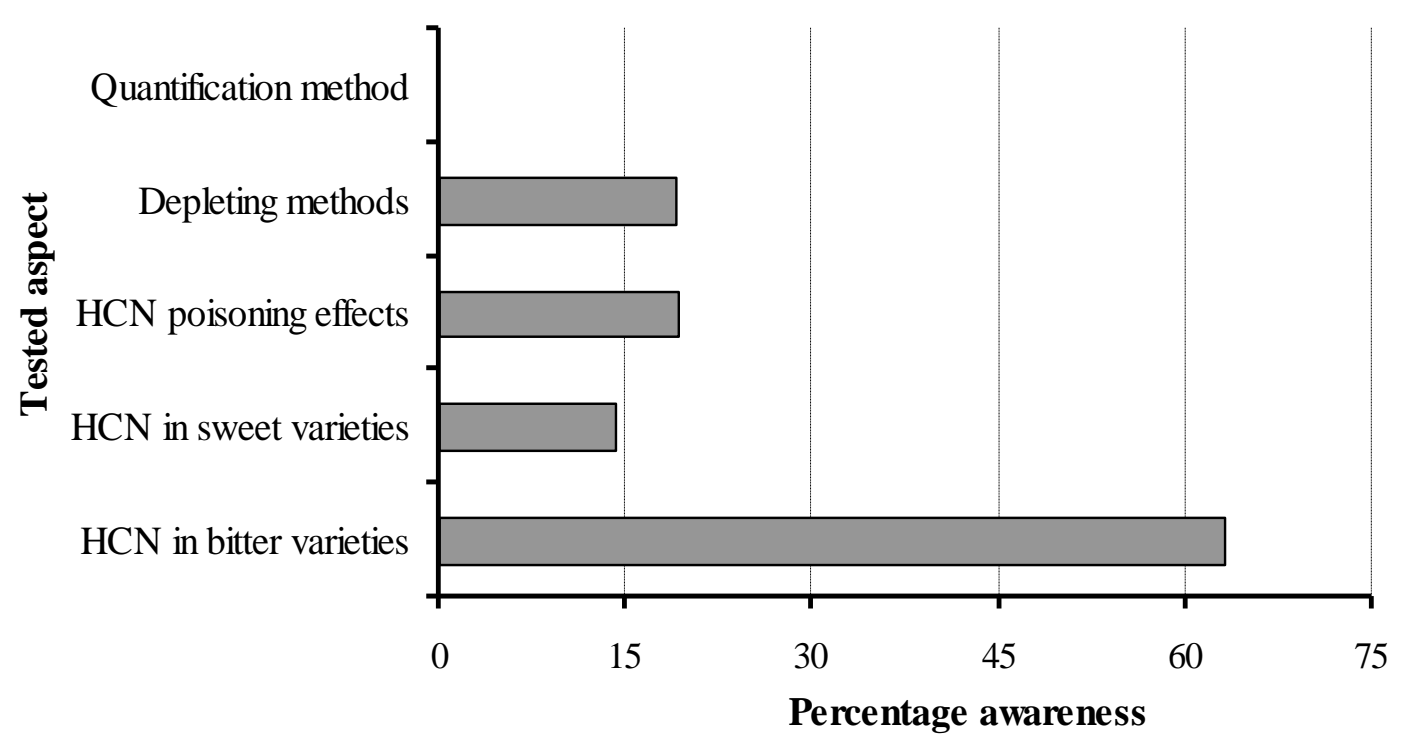

Figure 3. Peoples' awareness on different aspects of cyanide poisoning from consumption of cassava

\section{Discussion}

\subsection{Cassava Varieties Grown in Kagera and Morogoro Regions}

The survey showed that different varieties were grown by considering one or a combination of qualities including palatability, maturity attainment duration, productivity, resistance to diseases and tuber shelf life. Growth to maturity differed from one variety to another, some maturing within six months like KATAAKYA while others maturing in a year or longer such as RUSHULA. This finding was in line with the observations made by Allem (2002) and Montagnac et al. (2009) that cassava cultivars differ in their ability to tolerate pest and diseases, yield, nutritional and cooking qualities of food products as well as maturity attainment. It was also noted that, the meanings of some local names of cassava varieties hint to the qualities of such varieties. For instance, SHELEKERA ("hide for") signifies productivity; SUNGUSUNGU ("fierce local guard") hints to bitterness; KATAAKYA ("flowers not") signifies early maturity; MATOKE ("like banana fruit") gives the idea of ease to cook; and KONYU ("salty") refers to palatability. One respondent commented that the same variety may exhibit inconsistent maturity age due to environmental factors such as climate and soil type. For instance, KIBAHA variety was cited as taking 8 months to mature in Kibaha (Coast Region), but taking longer when grown in the highlands of Morogoro region. On SUNGUSUNGU, a note was made that its harvest should be delayed otherwise one should be ready to bear with its bitterness in its early maturity. This is in line with the previous observation that cyanide levels decrease as cassava plants age (Hidayat et al., 2002; Chotineeranati et al., 2006).

\subsection{Cyanide Levels in Cassava Tubers and Varieties}

All the tested tubers contained cyanide with levels ranging from $20-227 \mathrm{mg} / \mathrm{kg}$ for Kagera varieties and from $23-117 \mathrm{mg} / \mathrm{kg}$ for Morogoro varieties. These levels were all above the acceptable limit of $10 \mathrm{mg} / \mathrm{kg}$ in human consumables (FAO, 1977). By considering mean 
cyanide content of $50 \mathrm{mg} / \mathrm{kg}$ as the cutoff point between sweet and bitter tubers (FAO, 1977; Mercola, 2016), only four varieties (AKIBA, RUSHULA NYACHILO, and KIBAHA) could be regarded as sweet. With the exception of the varieties NYACHILO, SUNGUSUNGU and PIKIPIKI, the remaining varieties contained samples in both categories, suggesting that a variety can exist in both sweet and bitter forms. With regard to cyanide levels in cassava tubers, the findings of this study are in favor of authors who hold that acyanogenic cassava varieties are non-existent and cyanide level in all cassava tubers are above the accepted amount in human consumables (Bradbury and Holloway, 1988; White et al., 1998; FAO, 2007). Human consumables containing cyanide levels above $10 \mathrm{mg} / \mathrm{kg}$ are not eligible for direct consumption unless appropriate methods for depleting cyanide are employed (FAO, 2007). Moreover, the noted inconsistency of cyanide levels within samples of the same variety means that cyanide level in one sample tuber can in no way be used as a standard for other samples of the same variety collected from different geographical areas. In other words, the same variety can exist in both sweet and bitter forms due to factors that affect cyanide levels in cassava including water stress (Tan, 1995; Bokanga et al., 2004; Gitebo et al., 2009), soil type (CIAT, 1989; Ekanayake, 1994; CHU, 2015) and application of fertilizers (De Bruijn, 1973; Endris, 1977; Wheeler et al., 1990; Cuvaca et al., 2015).

The observation that some sweet cassava varieties grown in Kagera and Morogoro regions differ significantly in cyanide content concurs with observations made by previous researchers that although all cassava cultivars/varieties contain cyanogenic glycosides, a wide variation in the concentration of cyanogens exists among different cultivars (Cardoso et al., 2004; CIAT, 2007). The categorization of sample tubers and varieties into sweet and bitter lines calls for conscious consideration of methods appropriate for reducing cyanide in consumables to acceptable levels. Tubers in sweet cassava form need be boiled prior to human consumption (Cardoso, 2004; FSANZ, 2004; Ubwa et al., 2015). For bitter ones, a more effective process for depleting cyanide than mere boiling is required before being cooked for human use (Ernesto et al., 2002; Cardoso et al., 2004; Nzwalo and Cliff, 2011). Whereas bitterness in taste is not always a guarantee of cyanide level (Dufour, 1994) as this could stem from chemicals other than cyanide (Bokanga, 1994), there are cases in which varieties known to be sweet have tubers with high cyanide content disqualifying them to be called sweet (CIAT, 1989; Ekanayake, 1994; Tan, 1994). In other words, neither taste nor name of variety is a sure method for identifying poisonous and non-poisonous cassava varieties.

\subsection{Effect of Altitude on Cyanide Level in Cassava Tubers}

Our current findings on the effect of altitude on mean cyanide level in cassava tubers concur with those reported by Oluwole et al., (2007) in a similar study, which compared cyanide content of Nigerian and Tanzanian varieties obtained from varying altitudes. Stress factors such as high temperature and drought in the lowland areas may account for higher cyanide glycosides content in tubers of the same variety raised/cultivated in lowland areas. In our questionnaire survey we also found that in Morogoro municipality, most cassava tubers consumed raw are grown in highland parts of the region such as in the slopes of Uluguru Mountains. 
4.4 Distribution of Cyanide Between the Upper and Inner Tissue of Cassava Parenchyma

The results revealed significantly higher $(\mathrm{P}<001)$ cyanide content in the slippery upper issue than in the inner parenchyma suggesting that cyanide is not evenly distributed within the tuber. Several methods have been employed to reduce cyanide levels in cassava tubers (Ernesto et al., 2002; Nzwalo and Cliff, 2011). In the current study, the interest was focused on finding out if the practice of scratching off the slippery tissue of sweet cassava tuber (evident in Kagera region) could significantly reduce cyanide content in the tuber. This study has clearly proven that the upper parenchyma tissue is richer in cyanide than the inner tissues; thus justifying the habit of scratching of the slippery upper tissue prior to consumption or cooking cassava tubers.

\subsection{People's Awareness About Cyanide and Its Poisoning Effects}

The finding that about $80 \%$ of the respondents in this study were ignorant about the effects of cyanide poisoning including the knowledge of bitter and sweet varieties was a clear indication that consumption of raw cassava can have potential health concerns. Peoples' habit of consuming raw cassava tubers in the study area was therefore mostly cultivated by lack of awareness about cyanide in cassava and its poisoning effects. According to a respondent in the current study, a fatal case of cyanide poisoning happened in Kauzeni, Mvomero District in 2016. Ravindra (2007) supports the fact lack of education is one of the major factors contributing to neurotoxic disorders, namely, lathyrism, Konzo, and TAN. The mentioned ways commonly used by people to identify poisonous cassava tubers, such as previous experience on the variety and tasting are misleading. It has been shown that cassava varieties can display inconsistency of cyanide level due to different factors (Tan, 1994; Ekanayake, 1994; CIAT, 1989) and the same variety can exist in both sweet and bitter forms. Moreover, the degree of sweetness or bitterness does not necessarily foretell the degree of cyanide level in cassava tubers (Bokanga, 1994; Dufour, 1994). It is thus risky to consume raw cassava tubers whose cyanide level is unknown (Ubwa et al., 2015; FSANZ, 2004).

\section{Conclusions}

It is concluded that all cassava tubers that were analyzed in the current study had cyanide content above the internationally acceptable levels and thus consumption of such tubers in their raw state can lead to poisoning effects. Since the practice of characterizing a cassava variety as sweet or bitter can be misleading, measured cyanide levels should be used as a basis for categorizing cassava varieties in terms of their cyanide glycosides content. The finding that the upper (slippery) parenchyma tissue contains more cyanide glycosides than the inner tissue confirms that the practice of scratching off this slippery layer prior to boiling of tubers is not superfluous and should be promoted as one of the cyanide depletion methods. Availing people with new cassava varieties should go hand-in-hand with provision of education on cyanide poisoning effects as well as appropriate methods for depleting cyanide to acceptable levels for human consumption. Development of simple, cheap and rapid techniques to quantify cyanide in cassava tubers is recommended. 


\section{Acknowledgements}

The authors would like to thank Sokoine University of Agriculture for contributing to the success of this work.

\section{Conflict of interest}

No conflict of interest associated with this work.

\section{References}

Allem, A. C. (1994). The origin of Manihot esculenta Crantz (Euphorbiaceae). Genetic Resources and Crop Evolution, 41, 133-150. https://doi.org/10.1007/BF00051630

Allem, A. C. (2002). The Origins and Taxonomy of Cassava. In; Cassava: Biology, Production and Utilization; Hillocks, R.J., Thresh, J.M., Bellotti, A.C., Eds.; CABI Publishing: Oxon, UK. pp. 1-16. https://doi.org/10.1079/9780851995243.0001

AOAC (1995). Official method 915.031: Hydrocyanic acid in beans. Official Methods of Analysis.CAS-74-90-8.

Babalola, O. O. (2014). Cyanide content of commercial gari from different areas of Ekiti State, Nigeria. World Journal of Nutrition and Health, 2(4), 58-60.

Bokanga, M. (1994). Cassava variety: what is the problem? Paper presented at the $10^{\text {th }}$ Symp. of the Intern. Soc. for Trop. Root Crops, Salvador, Brazil, 13-19 Nov. 1994. Organizers: Intern. Soc. Trop. Root Crops, EMBRAPA, CIAT and IITA.

Bokanga, M., Essers, S., Pouler, N., Rosling, H., Tewe, O., Asiedu, R., \& Brader, L. (2004). International workshop on cassava safety. Acta Horticulturae, 375, 1-17.

Bradbury, J. H., \& Holloway, W. D. (1988). Chemistry of tropical root crops: significance for nutrition and agriculture in the Pacific. Australian Centre for International Agricultural Research, Monograph No 6, Canberra, Australia.

Cardoso, A. P., Mirione, E., Ernesto, M., Massaza, F., Cliff, J., Haque, M. R., \& Bradbury, J. H. (2004). Processing of cassava roots to remove cyanogens. Journal of Food Composition and Analysis, 18(2005), 451-460. https://doi.org/10.1016/j.jfca.2004.04.002

Chotineeranat, S., Suwansichon, T., Chompreeda, P., Piyachomkwan, K., Vichukit, V., Sriroth, K., \& Haruthaithanasan, V. (2006). Effect of root ages on the quality of low cyanide cassava flour from Kasetsart 50. Kasetsart Journal of Natural Science, 40, 694-701.

CHU, J. (2015). Cyanides and food safety. Food Safety Focus (110 ${ }^{\text {th }}$ Issue, September 2015) - Incident in Focus: Centre for Food Safety. Hong Kong.

CIAT (1989). Stretching the Water-Stress Limits of Cassava. Centro Internacional De Agricultura Cali, Colombia, 98pp.

CIAT (2007). Improved Cassava for the Developing World. Centro Internacional De Agricultura Cali, Colombia, 39pp. 
Cuvaca, I. B., Eash, N. S., Zivanovic, S., Lambert, D. M., Walker, F., \& Rustrick, B. (2015). Cassava (Manihot esculenta Crantz) tuber quality as measured by starch and cyanide (HCN) affected by nitrogen, phosphorus, and potassium fertilizer rates. Journal of Asian Studies, 7(6). https://doi.org/10.5539/jas.v7n6p36

De Bruijn, G. H. (1973). The cyanogenic character of cassava (Manihot esculenta). Chronic cassava toxicity Proceedings of an interdisciplinary workshop. London, England: Mt. Develop. Res. Centre Monogr. IDRC-OLOe. pp. 43-48.

Dufour, D. L. (1994). Role of cassava in diet: Amazonia and urban areas of Latin America. Paper presented at the $2^{\text {nd }}$ intern. Scientific meeting of the cassava biotechnology network, Bogor, 22-26 Aug. 1994. Organizers: Cassava Biotechnology Network, CIAT and Central Res. Inst. For Food Crops, Indonesia.

Ekanayake, I. J. (1994). A review of production agronomy and cyanogenesis. Paper presented at the $2^{\text {nd }}$ intern. Scientific meeting of the cassava biotechnology network, Bogor, 22-26 Aug. 1994. Organizers: Cassava Biotechnology Network, CIAT and Central Res. Inst. For Food Crops, Indonesia.

Endris, S. (1977). Cyanogenic potential of cassava cultivars grown under varying levels of potassium nutrition in Southwestern Ethopia. Ethiopian Institute of Agricultural Research (EIAR), Jimma Center, PO Box 192, Jimma.

Ernesto, M., Cardoso, A. P., Nicala, D., Mirione, E., Massaza, F., Cliff, J., \& Bradbury, J. H. (2002). Persistent konzo and cyanogen toxicity from cassava in northern Mozambique. Acta Tropica, 82(3), 357-362. https://doi.org/10.1016/S0001-706X(02)00042-6

Famurewa, J. A. V., \& Emuekele, P. O. (2014). Cyanide reduction pattern of cassava (Manihot Esculenta) as affected by variety and air velocity using fluidized bed dryer. African Journal of Food Science and Technology, 5(3), 75-80.

FAO (1977). Traditional storage of yams and cassava and its improvement- Cassava. [http://www.fao/inpho/content/vlibrary/gtzhtml] site visited on 12/07/2017.

FAO (2007). June 2003 Cassava market assessment [www.fao.org/docrep/019/i 3473e/i3473 e.pdf] site visited on 14/07/2017.

FAO (2013). Save and grow: cassava [www.fao.org/docrep/019/i3473e/i3473e.pdf.] site visited on 10/07/2017.

FSANZ (2005). Cyanogenic Glycosides in Cassava and Bamboo Shoots. A Human Health Risk Assessment. Food Standard Australia New Zealand, Canberra [https:/www.foodstandards.gov.au/_srcifiles/28_Cyanogenic_glycosides.pdf] site visited on $10 / 07 / 2017$

Gitebo, D. N., Banea-Mayabu, J. P., Matadi, R. N., Tylleskar, T., Gebre-Medhin, M., \& Rosling, H. (2009). Geographical and seasonal association between linamarin and cyanide exposure from cassaca and the upeer motor neuron disease konzo in DRC. In CCDN News, Issue 14. 
Hidayat, A., Zuraida, N., \& Hararida, I. (2002). The cyanogenic potential of roots and leaves of ninety nine cassava cultivars. Indonesian Journal of Agricultural Science, 3(1), 25-32. https://doi.org/10.21082/ijas.v3n1.2002.25-32

Idible, C. A. (2006). Isolation of pure cassava linamarin as an anticancer agent. Johannes: University of the Witwatersrand.

Kariuki, S. M., Abubakar, A., \& Kombe, M. (2017). Burden, risk factors, and comorbidities of behavioural and emotional problems in Kenyan children: a population-based study. Lancet Psychiatry, 4, 136-145. https://doi.org/10.1016/S2215-0366(16)30403-5

Kobawila, S. C., Louembe, D., Keleke, S., Hounhouigan, J., \& Gamba, C. (2005). Reduction of the cyanide content during fermentation of cassava roots and leaves to produce bikedi and ntobambodi, two food products from Congo. African Journal of Biotechnology, 4(7), 689-696. https://doi.org/10.5897/AJB2005.000-3128

Mburu, F. W. (2013). Potential Toxic Levels of Cyanide in Cassava (Manihot Esculenta Crantz) Grown in Some Parts of Kenya. Kenyatta University.

Mburu, F., Njue, W., \& Sauda, S. (2011). Fatal cassava food poisoning in Eastern Province. Kenya Cassava Cyanide Disease and Neurolathyrism Network (CCDN), 18, 1-2.

Mercola (2016). What is cassava good for? articles. [mercola.com/sites/articles /archive/2016/07/25/cassava.benefits.aspx] site visited on 12/04/2017.

Montagnac, J. A., Davis, C. R., \& Tanumihardjo, S. A. (2009). Nutritional value of cassava for use as a staple food and recent advances for improvement. Comprehensive Reviews in Food Science and Food Safety, 8, 181-194. https://doi.org/10.1111/j.1541-4337.2009.00077.x

Ngugi, A. K., Bottomley, C., \& Kleinschmidt, I. (2013). Prevalence of active convulsive epilepsy in sub-Saharan Africa and associated risk factors: Cross-sectional and case-control studies. Lancet Neurol, 12, 253-263. https://doi.org/10.1016/S1474-4422(13)70003-6

Nhassico, D., Muquingue, H., Cliff, J., Cumbana, A., \& Bradbury, J. H. (2008). Rising African cassava production, diseases due to high cyanide intake and control measures. Journal of the Science of Food and Agriculture, 88(12), 2043-2049. https://doi.org/10.1002/jsfa.3337

Nzwalo, H., \& Cliff, J. (2011). Konzo: from poverty, cassava, and cyanogen intake to toxico-nutritional neurological disease. PLOS Neglected Tropical Diseases, 5, e1051. https://doi.org/10.1371/journal.pntd.0001051

Oluwole, O. S. A., Onabolu, A., Mtunda, K., \& Mlingi, N. (2007). Characterization of cassava (Manihot esculenta Crantz) varieties in Nigeria and Tanzania, and farmers' perception of toxicity of cassava. Journal of Food Composition and Analysis, 20(7), 559-567. https://doi.org/10.1016/j.jfca.2007.04.004

Ravindra, K. G. (2007). Lathyrism, Konzo and TAN. [http://www.medlink.com/article/lathyrism_konzo_and_tropical_ataxic_neuropathy] site 
visited on $12 / 04 / 2017$

Smith, S. (2013). Determining sample size: How to ensure you get the correct sample size [https://www.qualtrics.com>researc] site visited on 12/7/2017.

Tan, S. L. (1995). Factors affecting cyanide content in cassava (Manihot esculenta Crantz). Journal of Tropical Agriculture and Food Science/MARDI Res. J., 23(2), 121-131.

Tivana, L. D., Francisco, J. D. C., Zelder, F., Bergenståhl, B., \& Dejmek, P. (2014). Straightforward rapid spectrophotometric quantification of total cyanogenic glycosides in fresh and processed cassava products. Food Chemistry, 158, 20-27.

https://doi.org/10.1016/j.foodchem.2014.02.066

Ubwa, S. T., Otache, M. A., Igbum, G. O., \& Shambe, T. (2015). Determination of cyanide content in three sweet cassava cultivars in three local government areas of Benue State, Nigeria. Food and Nutrition Sciences, 6(12), 1078. https://doi.org/10.4236/fns.2015.612112

Wheeler, J. L., Mulcahy, C., Walcott, J. J., \& Rapp, G. G. (1990). Factors affecting the hydrogen cyanide potential of forage sorghum. Australia Journal of Agricultural Research, 41(6). https://doi.org/10.1071/AR9901093

White, W. L., Arias-Garzon, D. I., McMahon, J. M., \& Sayre, R. T. (1998). Cyanogenesis in cassava the role of hydroxynitrilelyase in root cyanide production. Plant Physiology, 116(4), 1219-1225. https://doi.org/10.1104/pp.116.4.1219

\section{Copyright Disclaimer}

Copyright for this article is retained by the author(s), with first publication rights granted to the journal.

This is an open-access article distributed under the terms and conditions of the Creative Commons Attribution license (http://creativecommons.org/licenses/by/4.0/). 